\title{
Environmental impacts of electricity self-consumption from organic photovoltaic battery systems at industrial facilities in Denmark
}

\author{
Chatzisideris, Marios Dimos; Laurent, Alexis; Hauschild, Michael Zwicky; Krebs, Frederik C
}

Published in:

C I R P Annals

Link to article, DOI:

10.1016/j.cirp.2017.04.100

Publication date:

2017

Document Version

Peer reviewed version

Link back to DTU Orbit

Citation (APA):

Chatzisideris, M. D., Laurent, A., Hauschild, M. Z., \& Krebs, F. C. (2017). Environmental impacts of electricity self-consumption from organic photovoltaic battery systems at industrial facilities in Denmark. $C$ I R P Annals, 66, 45-48. https://doi.org/10.1016/j.cirp.2017.04.100

\section{General rights}

Copyright and moral rights for the publications made accessible in the public portal are retained by the authors and/or other copyright owners and it is a condition of accessing publications that users recognise and abide by the legal requirements associated with these rights.

- Users may download and print one copy of any publication from the public portal for the purpose of private study or research.

- You may not further distribute the material or use it for any profit-making activity or commercial gain

- You may freely distribute the URL identifying the publication in the public portal 


\title{
Environmental impacts of electricity self-consumption from organic photovoltaic battery systems at industrial facilities in Denmark
}

\author{
Marios D. Chatzisideris ${ }^{\mathrm{a}, *}$, Alexis Laurent ${ }^{\mathrm{b}}$, Michael Z. Hauschild (1) ${ }^{\mathrm{b}}$, Frederik C. Krebs ${ }^{\mathrm{a}}$ \\ ${ }^{a}$ Department of Energy Conversion and Storage, Technical University of Denmark, Roskilde, Denmark \\ ${ }^{\mathrm{b}}$ Division for Quantitative Sustainability Assessment, Department of Management Engineering, Technical University \\ of Denmark, Lyngby, Denmark
}

\begin{abstract}
Organic photovoltaics (OPV) show promise of greatly improving the environmental and economic performance of PV compared to conventional silicon. Life cycle assessment studies have assessed the environmental impacts of OPV, but not under a self-consumption scheme for industrial facilities. We investigate the life cycle environmental impacts of electricity self-consumption from an OPV system coupled with a sodium/nickel chloride battery at an iron/metal industry in Denmark. Results show that an OPV system without storage could decrease the carbon footprint of the industry; installation of the battery increases climate change and human toxicity impacts. We discuss sensitive modelling parameters and provide recommendations.
\end{abstract}

$\mathrm{CO}_{2}$ emission, lifecycle, organic photovoltaics

\section{Introduction}

Photovoltaics (PV) are expected to play a key role in the race to mitigate climate change [1]. Self-consumption of PV-generated electricity has become more attractive than exporting it to the grid with fading feed-in tariffs and rising retail electricity prices at residential level [2]. Moreover, decreasing costs of small-scale battery systems have enabled increasing coupling of PV with battery storage, thus allowing for increased self-consumption [3]. In the long term, self-consumption based on PV battery systems may offer the most economical solution compared to PV alone or the grid [2]. In the context of manufacturing industries, on-site generation has become an alternative to conventional electricity grid supply, despite its operation management challenges [4].

Organic PV (OPV) is an emerging technology that shows promise of greatly improving the environmental and economic performance of PV compared to conventional silicon-based technologies. OPV belong to the thin-film PV technologies utilizing abundant, non-toxic organic/polymer materials to absorb light and convert it into electricity. They are typically built in multiple layers that are deposited on plastic foil by high-throughput printing and coating techniques [5]. Compared to conventional PV, OPV modules exhibit advantageous installation features such as thin design, low weight, material flexibility, semi-transparency (making integration into window or glass facades possible) as well as fast and easy (de)installation. Until now, shorter lifetimes and lower power conversion efficiencies have not allowed OPV module prices to compete with conventional PV at market level [6]. However, their low weight qualify them for installation on roofs of industrial facilities where the roofing cannot withstand heavy structures typically required for the heavier conventional PV. In addition, fast and easy (re)installation can overcome the shorter lifetimes of 2-5 years that represent the current state-of-the-art. Thus, in the near future, OPV could offer lower energy costs and decreased environmental impacts associated with electricity consumption based on own production to industrial facilities with limited structural capacity .

Previous publications have assessed the environmental impacts associated with electricity generation from OPV technologies based on life cycle assessment (LCA) studies (see review by Chatzisideris et al. [7]). Focus in these studies has been on impacts at technology level, under the assumption that all generated electricity is exported to the grid thus replacing grid electricity from other sources. The potential for reducing environmental impacts of industrial facilities through OPV for self-consumption has not been examined.

The purpose of this paper is to address this gap by assessing how industries from different branches in Denmark could potentially reduce the environmental impacts caused by their electricity consumption when implementing selfconsumption of OPV-generated electricity with or without battery storage. The analysis was performed under Danish (DK) conditions, but the applicability of the approach to other regions is also discussed. 


\section{Methods}

\subsection{Modelling of OPV battery system self-consumption}

A model was developed to simulate the electricity flows at an electricity consumer with an OPV battery system installation allowing for self-consumption. Time series data sets with hourly values of electricity consumption and solar irradiation over a typical year in Denmark were used as inputs to the model.

The electricity consumption time series data were modelled based on hourly load profiles developed by the Danish Energy Association, with measurement-based electricity consumption data of Danish electricity consumers from 2012 (http://www.elforbrugspanel.dk). In the study, focus is on the iron/metal industry as one of the most electricity intensive sectors of the Danish industry. To offer comparison, electricity consumption data was also modelled for three other important electricity consumers with different consumption patterns: the chemical industry sector, the retail sector and residential houses.

Solar irradiation data were taken from the Danish Meteorological Institute (http://irradiance.dmi.dk) based on a data set representing a typical year and specifically developed for computer simulations. Electricity generation from the OPV system was calculated as:

$$
O P V_{\text {output }}=\text { solar irradiation } \times P C E \times \text { module area } \times P R
$$

The OPV system parameters were modelled based on the study by Espinosa et al. [8]. More specifically, an installation on a horizontal plane was assumed with a 5\% module power conversion efficiency (PCE), a 5-year module lifetime, an $80 \%$ performance ratio (PR) and a system lifetime of 35 years.

Economic performance is highly dependent on volatile energy taxation or subsidies, and it was considered outside the scope of this study, so no optimal economic sizing of the OPV capacity was performed. Instead, a range of OPV capacity values were used, calculated as a ratio of the annual electricity generation to the annual load consumption (e.g. for an OPV system at $100 \%$ capacity size, its annual OPV generation is equal to the annual electricity consumption).

The coupling of the OPV system with battery storage was modelled based on sodium/nickel chloride batteries, which have been demonstrated to be suitable for industrial applications [9]. According to Scenario B of the study by Longo et al. [9], the roundtrip efficiency was assumed at 90\%, the depth of discharge was taken at 95\% and a useful lifetime of 2187 days was considered. Similar to the approach taken for PV capacity sizes, a range of battery storage capacity values of up to $0.2 \%$ were used, calculated as the ratio of storage capacity to annual OPV electricity generation. To put this figure into perspective, a rule of thumb for cost optimal sizing of residential PV batteries was found in the range of $0.1-0.15 \%$ capacity levels [10].

In our model, electricity flows were simulated by comparing OPV generation and electricity consumption values on an hourly basis according to the following rules:

- OPV system without battery storage: if OPV generation was lower than consumption, the deficit was supplied by the grid; if OPV generation was higher than consumption, the OPV surplus was exported to the grid.

- OPV system with battery storage: if OPV generation was lower than consumption, available stored electricity was used from the battery (discharge), and when the battery was fully discharged, the deficit was supplied by the grid; if OPV generation was higher than consumption, the OPV surplus charged the battery, and when the battery was fully charged, the OPV surplus was exported to the grid.

Based on this comparison, the total locally consumed OPV-generated electricity (directly from the PV or through discharge of the battery) was calculated over a typical year. This enabled to calculate the self-sufficiency, which is defined as the ratio of the total locally consumed OPV-generated electricity to the total electricity consumption of the facility over a year [2].

\subsection{Scope of the environmental impact assessment}

For the study of the electricity consumption of an iron/metal industry, the functional unit, expressing the basis of comparisons of the environmental impacts, was defined as the average supply of $1 \mathrm{kWh}$ to the industry.

Fig. 1 shows the three different systems under comparison from an LCA modelling perspective. System A expresses the baseline situation where no OPV system is installed, and the DK grid satisfies electricity demand. In System B, an OPV system is installed for self-consumption, while the part of OPV-generated electricity that is not consumed locally is exported to the grid. In System C, battery storage is added for increased self-consumption. Thus, in Systems 
$\mathrm{B}$ and $\mathrm{C}$, the environmental profile of the industry's electricity consumption was calculated based on the sum of locally consumed OPV-generated electricity and imported electricity from the DK grid, where the balance was indicated by the self-sufficiency calculation results. In addition, exported electricity was assumed to replace marginal electricity sources, and thus to save their associated environmental impacts.

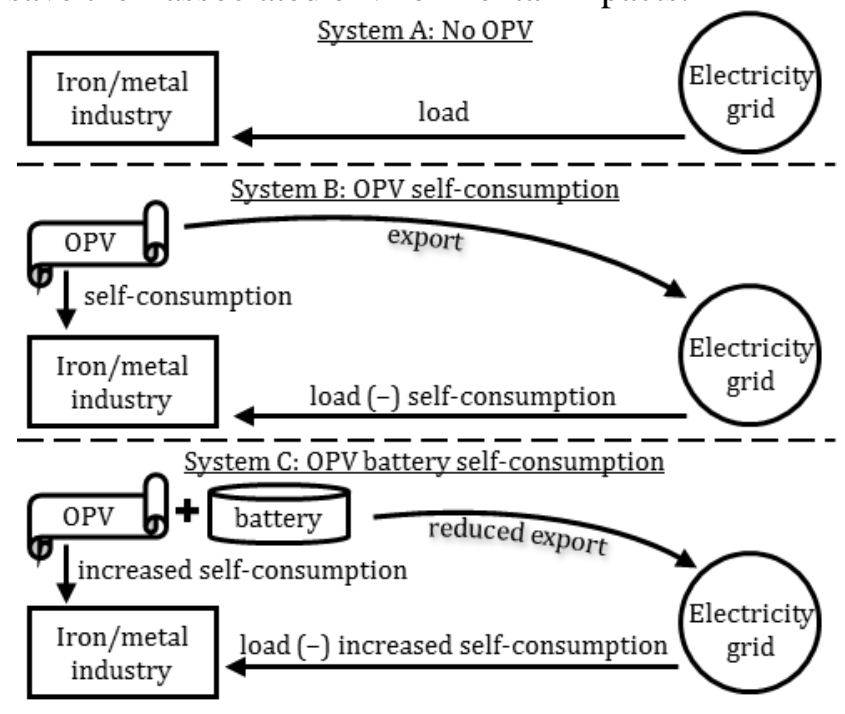

Fig. 1. Systems under study.

The environmental profile of the OPV battery system was calculated based on results from previous LCA studies on an OPV system [8] and a sodium/nickel chloride battery [9]. Both studies used the International Reference Life Cycle Data System (ILCD) [11] life cycle impact assessment method. Two impact categories were selected as relevant for this study: climate change and human toxicity. When shifting electricity generation from fossil-based to renewable technologies, climate change impacts have been shown to co-vary with impact categories such as acidification and photochemical ozone formation but not with human toxicity and resource depletion [12]. Therefore, human toxicity was considered as a complementary impact category to represent toxicity-related impacts (incl. ecotoxicity impacts). For human toxicity, cancer and non-cancer effects were aggregated; the impact scores were expressed in comparative toxicity units for humans $\left(\mathrm{CTU}_{\mathrm{h}}\right)$ reflecting the estimated increase in mortality and morbidity in the total human population as a result of the system implementation. Although resource depletion could also be relevant for investigation, it could not be assessed because the indicator was not reported for the battery in the study by Longo et al [9]. Future studies should cover all impact categories to identify the most problematic ones, as shown by Chatzisideris et al. [7] for thin-film PV technologies.

The environmental impacts of the Danish electricity grid at medium voltage level were calculated with the ILCD v.1.08 LCIA method [11] in SimaPro v.8.2 with the ecoinvent 3.2 database [13] (reference year 2012). In the modelling of the electricity flows, the industry was assumed to consume electricity from the average Danish grid mix, as in the absence of OPV system, while exports of electricity from the OPV system to the grid were assumed to substitute marginal electricity sources, i.e. Danish wind power as a default scenario [13]. To address the uncertainty of this modelling assumption, a sensitivity analysis was performed, considering modelling of the exports with alternative electricity sources. No transmission losses were considered.

\section{Results and discussion}

\subsection{Self-sufficiency of industrial, commercial and residential consumers without storage}

Fig. 2 compares the self-sufficiency ratio of an iron/metal industry with that of another important industrial electricity consumer (chemical industry), a commercial (retail), and a residential consumer at different capacity levels of PV production. The self-sufficiency curves of the iron/metal industry, chemical industry and residential consumers showed similar trends with self-sufficiency ranging from $22 \%$ to about $39 \%$ with growing PV capacities, while the retail sector performed better ranging from $24 \%$ to $45 \%$ depending on PV capacity. To investigate why retail performed better, a month-by-month self-sufficiency calculation revealed that retail performed better every month, and, especially during sunnier months June-August, when retail's electricity consumption was higher compared to the rest of year on average, while consumption of the other consumer categories was lower. 


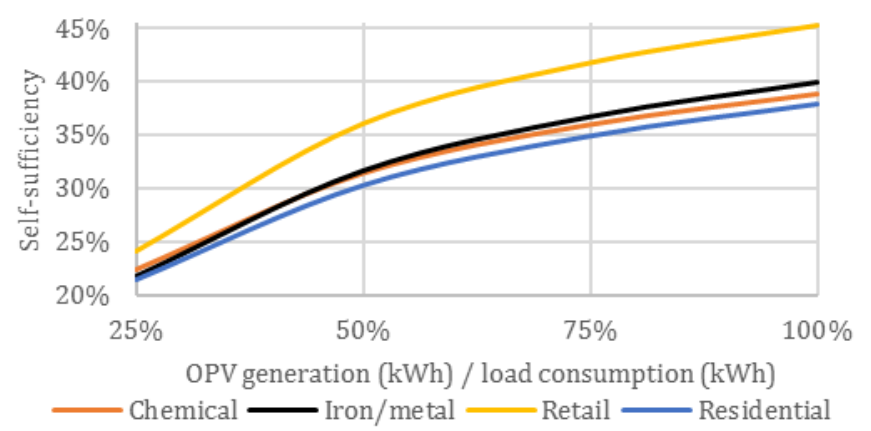

Fig. 2. Self-sufficiency potential of industrial, commercial and residential consumers based on self-consumption from OPV without storage.

\subsection{Self-sufficiency of an iron/metal industry with battery storage}

Fig. 2 shows self-sufficiency performances for an OPV system without battery. In Fig. 3 we investigate the effect on the self-sufficiency for the iron/metal industry of including battery storage with a capacity up to $0.2 \%$ of the OPV capacity. The figure shows how self-sufficiency increases with storage capacity, particularly for the higher levels of installed OPV capacity; an OPV system sized at $100 \%$ of the load can increase self-sufficiency from $40 \%$ to about $64 \%$, while a smaller PV system sized at $25 \%$ of the load benefits little from the installation of storage capacity and only increases self-sufficiency from $22 \%$ to $24 \%$. As also visible in Fig. 3, for higher installed PV capacities, the greatest benefits are harvested with installed battery capacity of up to $0.08-0.1 \%$ of the OPV capacity after which the benefit levels off.

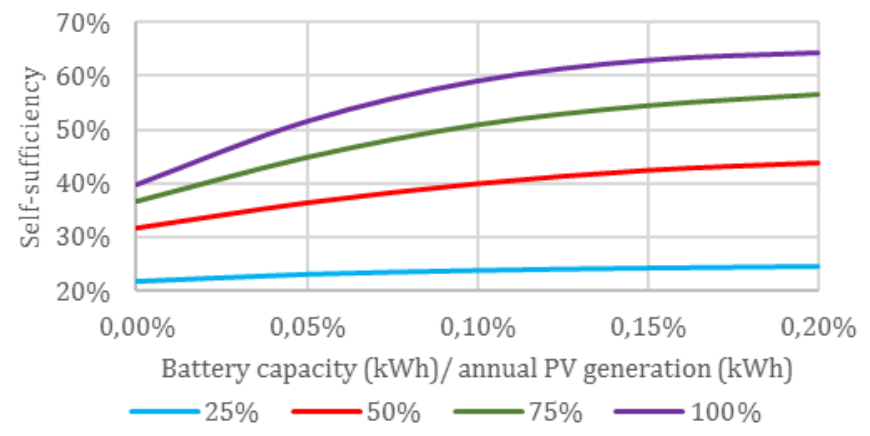

Fig. 3. Self-sufficiency of an iron/metal industry based on self-consumption from OPV with battery storage. The four curves refer to OPV capacity values calculated as the ratio of annual electricity generation to annual load consumption.

\subsection{Environmental impacts of $O P V$ and battery self-consumption}

The climate change impacts of an OPV battery system were calculated at $0.071 \mathrm{~kg} \mathrm{CO}$ eq $/ \mathrm{kWh}$ produced without storage, and at $0.744,1.41,2.09$, and $2.76 \mathrm{~kg} \mathrm{CO} 2 \mathrm{eq} / \mathrm{kWh}$ for the four battery capacities, $0.05 \%, 0.1 \%, 0.15 \%$ and $0.2 \%$, respectively. To put the results in perspective, the 2012 carbon footprints of the DK grid at medium voltage and of a coal-fired combined heat and power plant (CHP) were 0.315 and $0.885 \mathrm{~kg} \mathrm{CO}_{2} \mathrm{eq} / \mathrm{kWh}$ respectively [13]. An OPV system without storage would thus perform at less than $23 \%$ of the DK grid mix in terms of carbon footprint. In contrast, an OPV system with battery would perform worse than the grid; introducing sodium/nickel chloride battery storage would increase the climate change impacts of the OPV system significantly. Even at the lowest modelled battery capacity of $0.05 \%$, an OPV system with battery would have more than twice the carbon footprint of the grid mix, while adding further battery capacity would increase the footprint up to almost nine times that of the grid mix (ca. 39x higher than OPV without storage).

The human toxicity impacts from the life cycle of an OPV battery system were calculated at $1.6 \cdot 10^{-7} \mathrm{CTU}_{\mathrm{h}} / \mathrm{kWh}$ without storage, and at $3.5 \cdot 10^{-7}, 5.4 \cdot 10^{-7}, 7.3 \cdot 10^{-7}$ and $9.2 \cdot 10^{-7} \mathrm{CTU}_{\mathrm{h}} / \mathrm{kWh}$ for the four battery capacities, $0.05 \%$, $0.1 \%, 0.15 \%$ and $0.2 \%$, respectively. In comparison, the DK electricity grid mix had a life cycle human toxicity impact of $9.5 \cdot 10^{-8} \mathrm{CTU}_{\mathrm{h}} / \mathrm{kWh}$ in $2012[13]$ meaning that the human toxicity impacts from the life cycle of OPV 
without storage would be $1.7 \mathrm{x}$ higher, and from an OPV with $0.20 \%$ storage capacity about $10 \mathrm{x}$ higher than the DK grid mix.

Since introducing a sodium/nickel chloride battery would increase environmental impacts of the OPV system significantly, a contribution analysis to identify which parts of the battery's life cycle drive the environmental impacts was relevant. The analysis showed that the manufacturing of the battery drove the environmental impacts, in particular the energy consumed during the cell manufacturing process and the production of the necessary nickel powder were the top contributing factors to climate change and human toxicity impacts respectively [9].

The above OPV battery system life cycle impacts on climate change and human toxicity are combined with the selfsufficiency results shown in Fig. 3 to derive the environmental profile of the electricity consumption in an iron/metal industry as a function of different capacity levels of installed OPV system with battery storage. The results shown in Fig. 4 indicate that if an iron/metal industry installed an OPV system, climate change impacts would decrease if no storage was installed, while human toxicity impacts would increase (Fig. 5). More specifically, without storage the carbon footprint score would decrease ranging from $4 \%$ to $21 \%$ compared to the Danish electricity grid, depending on the installed OPV capacity. Installation of battery storage would worsen both impacts as previously described. In Fig. 4 and Fig. 5, the impact results for the OPV capacities 25, 50, 75 and 100\% are very similar, so the four curves are graphically overlapping.

A similar trend was observed in earlier studies where impacts of conventional PV systems coupled with lead-acid batteries were found to be unfavourable compared to PV without storage [14,15]. More specifically, Kabakian et al. assessed a stand-alone mono-Si PV with lead-acid batteries installed in Lebanon [14], and McKenna et al. [15] investigated the addition of lead-acid batteries to residential PV systems in the UK.

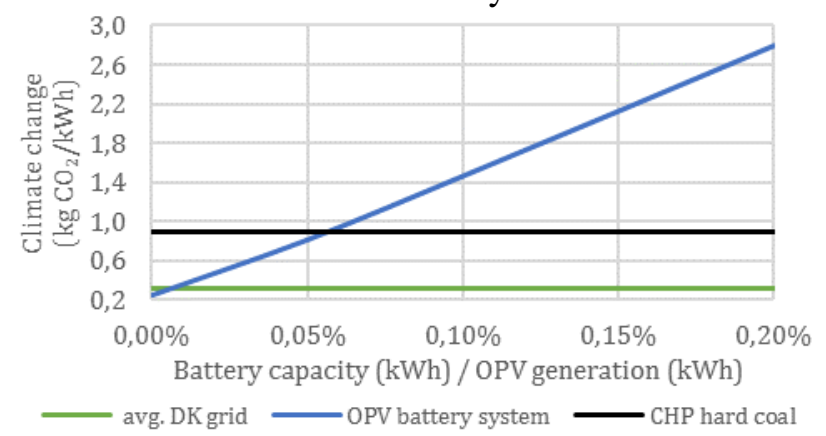

Fig. 4. Characterised impact scores for life cycle impacts on climate change from self-consumption of an iron/metal industry in Denmark with installed OPV with battery. The OPV battery curve refers to four graphically overlapping curves of OPV capacities 25, 50, 75 and $100 \%$ calculated as the ratio of annual generation to annual consumption.

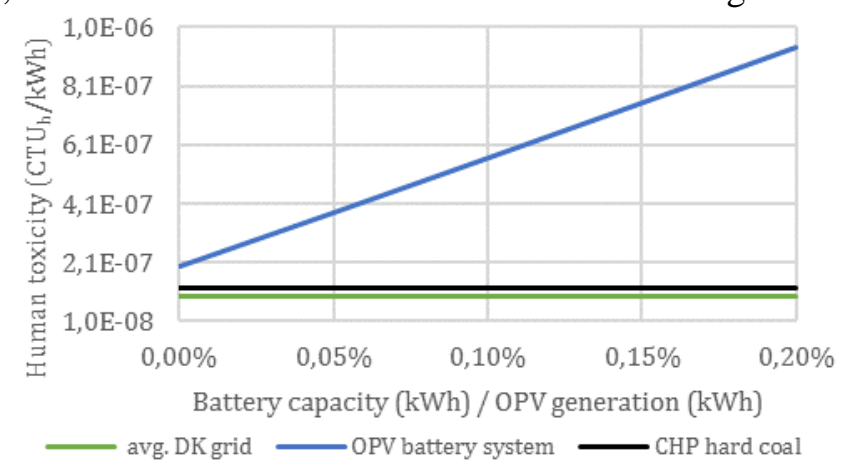

Fig. 5. Characterised impact scores for life cycle impacts on human toxicity from self-consumption of an iron/metal industry in Denmark with installed OPV with battery. The OPV battery curve refers to four graphically overlapping curves of OPV capacities 25, 50, 75 and $100 \%$ calculated as the ratio of annual generation to annual consumption.

\subsection{Sensitive parameters}

The environmental profile of the sodium/nickel chloride battery dominates the environmental impact results of the OPV battery system. To reverse results so that storage would offer environmental benefits, the carbon footprint of the battery would need to decrease to $12 \%$ or less at the lowest $0.05 \%$ capacity. Lead-acid or lithium-ion battery technologies may also be relevant for PV applications, but insufficient data were found; numerous LCA studies of 
batteries with focus on electric vehicles are available [16], but LCA studies of PV battery applications are rare [17]. Further research is needed in the field to produce more robust life cycle inventories and LCA studies, especially related with parameter data on charge/discharge patterns and cycle life.

Denmark has a low-carbon electricity grid with an increasing penetration of wind power; the 2012 carbon footprints of the Danish average grid mix and the marginal grid mix are 0.315 and $0.02 \mathrm{~kg} \mathrm{CO}$ eq/ $\mathrm{kWh}$, respectively. In comparison, the 2012 carbon footprints of the average grid mix and the marginal mix for Germany are 0.632 and $0.913 \mathrm{~kg} \mathrm{CO} 2 \mathrm{eq} / \mathrm{kWh}$, and for Europe the average values are 0.473 and $0.448 \mathrm{~kg} \mathrm{CO}_{2} \mathrm{eq} / \mathrm{kWh}$, respectively [13]. For a European average situation, installation of an OPV system for industrial self-consumption would thus decrease the life cycle climate change impacts about $80 \%$ without battery storage (compared to the decrease of $20 \%$ in Denmark; see Section 3.4). With battery storage it would still increase environmental impacts. These results show the importance of the marginal energy technology which varies strongly with the country or region, in which the OPV system is deployed. It should also be noted that in this sensitivity analysis, only electricity grid mixes were changed; a more complete analysis would require the consideration of average European values for solar irradiation and electricity consumption profiles.

\section{Conclusion and recommendations}

This study models the self-consumption of electricity generation from OPV battery systems by important electricity consumer types in Denmark, and assesses the life cycle impacts on climate change and human toxicity in an iron/metal industry.

The results show that an iron/metal industry performs similarly to other important electricity consumers in terms of self-consumption, but worse than retail. The environmental profile of OPV battery self-consumption in an iron/metal industry demonstrates that installation of an OPV system without storage, could decrease climate change impacts, but increase human toxicity impacts compared to consumption from the Danish electricity grid. Coupling the OPV system with a sodium/nickel chloride battery for storage would increase both impacts significantly over the replaced electricity grid mix.

A sensitivity analysis indicates that the sodium/nickel chloride battery dominates the environmental profile of the combined OPV battery system, and to reverse results so that storage would offer environmental benefits, the battery's environmental profile would need to improve drastically. Other parameters that may influence results are the country or region of deployment and its related average grid mix and long-term marginal electricity mix.

Based on our findings, industrial facilities where the roofing is too frail to withstand the heavier structures of conventional PV should consider the installation of lighter OPV systems to improve the carbon footprint of their electricity consumption. However, other impacts may increase with the installation, e.g. human toxicity. OPV system developers who consider coupling OPV with batteries for increased self-consumption should assess all relevant environmental impacts of the combined system. LCA practitioners and experts in the field of batteries for PV applications are encouraged (i) to perform LCI and LCA studies as current literature is limited (ii) to report all battery system modelling parameters enabling further modelling, and (iii) to consider all impact categories as required for scientifically sound LCA practice.

\section{Acknowledgement}

We acknowledge financial support from the Climate-KIC platform of the European Institute of Innovation and Technology.

\section{References}

[1] IEA (2015) Solar Photovoltaic Energy, OECD Publishing.

[2] Weniger J, Tjaden T, Quaschning V (2014) Sizing of Residential PV Battery Systems, Energy Procedia 46:7887.

[3] IRENA (2015) Battery Storage for Renewables: Market Status and Technology Outlook.

[4] Ghadimi P, Kara S, Kornfeld B (2015) Renewable energy integration into factories: Real-time control of on-site energy systems, CIRP Ann - Manuf Technol 64:443-6.

[5] Krebs FC, Espinosa N, Hösel M, Søndergaard RR, Jørgensen M (2014) 25th Anniversary Article: Rise to Power - OPV-Based Solar Parks, Adv Mater 26:29-39.

[6] Gambhir A, Sandwell P, Nelson J (2016) The future costs of OPV - A bottom-up model of material and manufacturing costs with uncertainty analysis, Sol Energy Mater Sol Cells 156:49-58. 
[7] Chatzisideris MD, Espinosa N, Laurent A, Krebs FC (2016) Ecodesign perspectives of thin-film photovoltaic technologies: A review of life cycle assessment studies, Sol Energy Mater Sol Cells 156:2-10.

[8] Espinosa N, Laurent A, Krebs FC (2015) Ecodesign of organic photovoltaic modules from Danish and Chinese perspectives, Energy Environ Sci 8:2537-50.

[9] Longo S, Antonucci V, Cellura M, Ferraro M (2014) Life cycle assessment of storage systems: the case study of a sodium/nickel chloride battery, J Clean Prod 85:337-46.

[10] Teknologisk Institut (2015) Solcelleanlæg til fællesforbrug.

[11] Hauschild MZ, Goedkoop M, Guinée J, Heijungs R, Huijbregts M, Jolliet O, et al. (2013) Identifying best existing practice for characterization modeling in life cycle impact assessment, Int J Life Cycle Assess 18:68397.

[12] Laurent A, Olsen SI, Hauschild MZ (2010) Carbon footprint as environmental performance indicator for the manufacturing industry, CIRP Ann - Manuf Technol 59:37-40.

[13] Wernet G, Bauer C, Steubing B, Reinhard J, Moreno-Ruiz E, Weidema B (2016) The ecoinvent database version 3 (part I): overview and methodology, Int J Life Cycle Assess 21:1218-1230.

[14] Kabakian V, McManus MC, Harajli H (2015) Attributional life cycle assessment of mounted 1.8kWp monocrystalline photovoltaic system with batteries and comparison with fossil energy production system, Appl Energy 154:428-37.

[15] McKenna E, McManus M, Cooper S, Thomson M (2013) Economic and environmental impact of lead-acid batteries in grid-connected domestic PV systems, Appl Energy 104:239-49.

[16] Peters JF, Baumann M, Zimmermann B, Braun J, Weil M (2017) The environmental impact of Li-Ion batteries and the role of key parameters - A review, Renew Sustain Energy Rev 67:491-506.

[17] Balcombe P, Rigby D, Azapagic A (2015) Environmental impacts of microgeneration: Integrating solar PV, Stirling engine CHP and battery storage, Appl Energy 139:245-59. 